\title{
4 Self-regulating informal transport workers and the quest for social protection in Tanzania
}

\author{
Godbertha Kinyondo
}

\section{Introduction}

In Tanzania, 90 percent of the cars, trucks, and buses are privately owned, and most people rely on affordable informal sector transportation such as motorcycles (bodaboda), rickshaws (bajaji), and minibuses (daladala). ${ }^{1}$ These informal transportation modes provide an important source of livelihood for operators (Cervero, 2000). The transportation sector accounts for 6 percent of total informal sector employment in the country and is male-dominated (ILFS, 2014; NBS, 2014a). In 2014/2015, the transportation and storage industry employed 2.6 percent of the 20 million working population in Tanzania. Workers in the transportation sector work up to 14 hours per day almost seven days a week, which violates labour laws. The Employment and Labour Law Act of 2004 (URT, 2004; PDL, 2014) stipulates that an employee may work six days a week, nine hours per day, or a total of 45 hours in a week.

The informal transport sector is prone to injuries and fatalities. In November 2018, the Deputy Minister for Home Affairs reported 8,237 deaths and 37,521 cases of lost-limb injuries involving motorcycle accidents between 2008 and 2018 (Vanguard, 2018). From 2016 to 2018, 3,719 motorcycle riders were injured in 4,624 road accidents (AllAfrica, 2019). Amidst such high levels of risks, the majority have no access to social health insurance. Often, informal transportation workers are the main family breadwinners, and their deaths and lifetime injuries can be a cause of poverty for the family (Mbegu \& Mjema, 2019).

Poor access to Social protection for informal transport workers mirrors the inadequate provision of social protection for the general population. Tanzania spends only 2 percent of its GDP on income security needs of older people, one of the lowest ratios in the world (ILO, 2018). In terms of health, in 2018, only 34 percent of the population was covered by health insurance. The largest insurance schemes are the National Health Insurance Fund (NHIF) and the Community Health Fund (CHF). NHIF is mandatory for civil servants and covers only 7 percent of the population (Wang et al., 2018; UNICEF, 2018). CHF, which is a public scheme meant to serve the rural and poor, covers 25 percent of the population, and private insurance covers 2 percent. In 2018, Tanzania merged the five duplicative pension schemes into two schemes: Public Service Social Security 


\section{Godbertha Kinyondo}

Fund (PSSSF) and the National Social Security Fund (NSSF). The new PSSSF serves the public sector ${ }^{2}$ while the NSSF caters for the informal sector ${ }^{3}$ and privatesector workers. Significantly, informal transport workers rely on their associations for their social protection.

Against the backdrop of the inadequacy of social protection for informal workers in Tanzania, this chapter employs the Devereux and Sabates-Wheeler (2004) social protection framework and utilizes the Power Resource Approach (PRA) to assess the relevance of transportation associations in meeting the social protection needs of daladala and bodaboda operators. It explores worker characteristics, social protection opportunities and challenges, forms of organizing, and how informal transport associations assist members in acquiring social protection. The chapter draws on survey data, focus group discussions (FGD), and Key informant Interviews (KII) conducted between August 2018 and February 2019 in Dar es Salaam and Dodoma. The survey covered 250 bodaboda and daladala drivers and conductors. The KII included association leaders and stakeholders in the governance of the informal transport sector, while FGDs included only members of selected associations.

The chapter is divided into nine sections. The following section looks at governance of the transport sector. The third section gives three examples of transportation associations followed by an analysis in section four based on the PRA. The fifth section presents the profile of the surveyed informal transportation workers, and section six looks at the key work-related threats and challenges facing informal transport workers. Section seven utilizes the Devereux and Sabates-Wheeler (2004) framework to describe the measures that informal associations take in regard to social protection and section eight discusses pertinent issues related to informal transport workers, their associations and SP, while section nine concludes and makes recommendations.

\section{Governance of the transportation sector}

This section describes how, in the face of the government's inability to effectively govern the informal transportation sector, informal sector workers take it upon themselves to coordinate their own operations.

\section{Government transportation institutions, policies, and regulations}

The Ministry of Works, Transport and Communications (MOWTC) is responsible for establishing transportation policy and has a broad mandate of overall planning and investment in roads, rail, waterways, and marine and air corridors. The National Transportation Policy of 2003 "allows private sector participation and market competition" but also calls for government oversight and regulation so that "workers and customers are protected against abuse" (URT, 2003). While MOWTC collects statistics related to motorcycles, bajaji, and minibuses, it does not exercise direct oversight of the informal transport sector. The Tanzanian National Roads Agency (TANROADS), a semi-autonomous agency within MOWTC, is responsible for the maintenance and development of trunk and regional road networks and undertakes road safety audits. 
The Land Transport Regulatory Authority (LATRA) was established by the Land Transport Regulatory Authority Act No. 3 of 2019 to regulate movement of goods and passengers by commuter buses, intercity buses, goods-carrying vehicles, taxi, motorcycles, and tricycles. LATRA replaced the Surface and Marine Transport Regulatory Authority (SUMATRA). In collaboration with the Dar es Salaam Commuter Bus Owners Association (DARCOBOA), LATRA allocates routes and fee structures for buses moving between urban areas.

The Ministry of Labour and Ministry of Health's are responsible for policies, that is, Social Security and Health Sector Strategic Plan, respectively, which envisage social protection for all but, unfortunately, lacks an implementation plan for the informal sector.

At the local level, the Local government authorities (LGAs) are responsible for the development and management of the public transport infrastructure like roads, terminals, and bus stops. LGAs issue vehicle licenses for bodaboda and daladala and establish passenger collection points and parking areas. The Police issue driving licenses and are responsible for enforcing safe driving behaviour and ensuring roadworthiness of vehicles. Further, they provide safety and security training for transportation workers and conduct rider awareness campaigns through print and broadcast media.

\section{Effectiveness of government transportation institutions}

Because LATRA does not have the broad scope of SUMATRA, it is hoped that its transportation oversight will be more effective. For example, at one point, SUMATRA required daladala owners to show legal contracts between them and licensed drivers before their mini-buses could be registered to operate for business. The frequency of submitting manipulated documents was so high that SUMATRA eventually abandoned the requirement. Also, SUMATRA sometimes assigned routes that had few customers. Drivers were thus tempted to drive on non-designed routes or cut the trip short. SUMATRA's defence was that it had insufficient staff and means for conducting adequate review and surveillance. Hopefully, LATRA will not have the same constraints.

LATRA's delegation of authority to LGAs to issue vehicle licenses and to set up parking and passenger collection points is meant to inspire local solutions to problems and to enhance enforcement of regulations and surveillance of bodaboda and daladala behaviour. However, LGAs are often stretched for resources and capacity to conduct these functions. Also, they may unwisely use their authority. For instance, the Regional Commissioner (RC) of Dar es Salaam ordered daladala to transport teachers without payment of bus fare on top of onboarding school children at a concessionary rate. This caused conductors to fill buses quickly with other passengers, drivers to skip pickup points where there were many students, and teachers to hide their IDs until after taking their seats. This unnecessary conflict and undue economic pressure could have been avoided by consulting local stakeholders first. 


\section{Godbertha Kinyondo}

Bodaboda disreputably move in and out of traffic lanes in disregard of traffic regulations and respect for other road users. Police rarely stop them for crossing intersections on red lights because it is a common behaviour. Bodaboda are keenly aware of the threat of having an accident due to their reckless behaviour, but this does not deter them from engaging in risky driving to accumulate adequate money for the day. Many passengers refuse to wear helmets because they are considered uncomfortable and dirty, and again enforcement is lax.

This section indicates fragmented strategies, lacking vertical and horizontal coordination, amongst echelons of government agencies, regarding the need, requirement, and regulation of the informal transport sector. Furthermore, agencies have limited financial and human resources to relate to informal transportation workers.

\section{Self-governance and collective organizing among informal transportation workers}

Over the years, daladala and bodaboda groups have arisen progressively, bound together by the social obligation to assist each other in need or under threat. They assemble in parking areas and around passenger collection points where they naturally share common problems in dealing with authorities or employers, as noted below:

our group came together to assist ourselves when one of us get involved in an accident, death, sickness of himself and or close family members; harassment by authority, conflict with bosses; we have a constitution that explain member's benefits depending on the situation...

(FGD participant DSM)

One of the common strategies of informal transport groups to gain negotiation leverage is to associate with a formal union. For example, Umoja wa Madereva na Dar es Salaam (UWAMADAR) was established by 42 drivers and conductors on 12 July 1997. In order to have an audience with the authorities, they were compelled to be affiliated with a trade union, COTWU-T. COTWU-T requested that UWAMADAR increase its membership to be a more legitimate entity, and by 2003 , the association had over 5,236 members (Rizzo, 2020).

However, UWAMADAR subsequently was weakened by leaders, who failed to call regular meetings because they, like their members, were on the road most of the time as fulltime drivers. Furthermore, UWAMADAR did not meet the requirements of legal representation, which is why it became an affiliate of COTWU-T. Eventually, UWAMADAR leaders left to form the Tanzania Road Transport Workers Union (TAROTWU), which represents drivers, conductors, and others working on buses. COTWU-T faced sector-specific factions ${ }^{4}$ as well, that is, Umoja wa Madereva Tanzania (UWAMATA), which represents only drivers who operate on upcountry routes; CHAWAMATA, representing drivers of lorries, and Tanzania Association of Drivers Union (TADU) that represents bodaboda workers and those that operate smaller vehicles like bajaji. 
Participation in transportation associations carries some risk. Elected officers, who may not be versed in financial management, can be duped. In some instances, a leader, who has personal needs or ambitions, may embezzle funds, which may go undetected for a long period. These leadership problems often result in the dissolution of associations and later re-establishment with a new leadership.

Generally, most informal transportation associations lack sufficient and durable power to negotiate with the authorities on their own. Furthermore, the constant fragmentation and disintegration of their associations only strengthen the hand of the authorities, who will continue to favour negotiating with unions which represent the formal transportation sector.

Despite internal weakness and external constraints under which informal transportation associations operate, several have demonstrated that it is possible for bodaboda and daladala to organize and become effective representative bodies. As the three examples below show, enlightened and able leadership is one of the key ingredients of success.

\section{Communications Transportation Workers Union of Tanzania ${ }^{5}$}

COTWU-T is an affiliate of the Trade Union Congress of Tanzania (TUCTA), which is the apex trade union in the country. It has nearly 6,000 members from the transport and telecommunication sectors. It operates through democratic structures of elected members to executive committees at national and branch levels and conducts a quadrennial conference. It has a woman's officer on its national executive committee.

The union mainly organizes formally employed workers in the transport and communication sector. However, faced with dwindling membership and encouraged by TUCTA, the union created an informal economy desk (IEDO) for the purpose of organizing informal transport workers. The IEDO participates in international fora to discuss key issues facing informal transport workers (KII, IEDO, Secretary General). TUCTA developed a draft policy that would mobilize the informal sector to form associations that would, in turn, link to larger associations and affiliate unions (TUCTA 2015).

COTWU-T has been proactive in reaching out to the informal transportation sector. They routinely invite leaders of informal transportation groups to their seminars and workshops. Facilitators include representatives from national government, such as NHIF, NSSF, and the police, which gives association leaders opportunity to not only learn but also nurture critical contacts at higher levels. These trainings also address matters such as social security, health insurance, and other support schemes.

When COTWU-T learned that the Matangini Michungwani King'ongo (MMK) association with 250 bodaboda members was having difficulties in registering as a formal association, COTWU-T intervened, which resulted in MMK gaining legal status as an affiliate branch of COTWU-T in April 2019. Prior to that, MMK existed as an informal self-help group of workers with the aim of 
welfare supporting one another. Despite COTWU-T reaching out to informal transportation worker groups, MMK has been one of the few associations taking advantage of what COTWU-T offers. On several occasions, COTWU-T has made legal services available to MMK, mostly disputes between bodaboda and the owners of motorcycles. MMK members credit COTWU-T for the membership ID card which protects them from harassment by authorities (FGD with MMK, 2019). MMK members of COTWU-T pay a monthly fee of TZS 1,000 or any amount dimmable, while formal members pay 2 percent of their salaries. MMK gained prominence after COTWU-T invited them to participate in the 'Labour Day parade', and their placard read: "Bodaboda is like any other job".

\section{Chama cha Madereva wa PikiPiki Dar-es-Salaam ${ }^{6}$}

Chama cha Madereva wa PikiPiki Dar-es-Salaam (CMPD) is an umbrella association of bodaboda drivers, boasting a total of 45,000 members in Dar es Salaam and was registered formally in September 2016. The association was established as a result of a meeting in April 2016 with the RC for Dar es Salaam. The RC, a young activist political leader, listened to their grievances about strenuous working conditions, abuse by owners, and harassment by traffic police. This resulted in forming a committee that included representatives of SUMATRA, police, and officials from the five districts.

The RC's request was that bodabodas form one single group with which he and the committee could continue discussions. At the time, there were three registered district-level bodaboda associations: from Ilala District, Chama Cha Waendesha Pikipiki Ilala (CHAWAPILA), from Kinondoni District, Chama Cha Bodaboda Wilaya ya Kinondoni (CHABOWIKI), and Temeke District, Umoja Wa Waendesha Pikipiki Temeke (UWAPITE). There were also various informal groups in Kigamboni and Ubungo districts.

With this high-level political support, CMPD negotiated with district authorities to reduce the area of the city centre that was prohibited entry by bodaboda. CMPD have since mediated several disputes between bodaboda drivers and motorcycle owners, who are more open to discussion, knowing that CMPD enjoys political support. CMPD also mediate disputes between bodaboda, daladala, and private drivers over access to different parking areas and over harassment of bodaboda as noted by a bodaboda respondent, "Drivers of big vehicles contribute towards bodaboda accidents as they do not respect bodaboda drivers when driving. They sometimes push bodaboda drivers deliberately to compel them to clear the way".

CMPD conducts trainings on safety and health issues and credits itself for reducing accidents and drivers' deaths. Other trainings have included topics on businesses management and customer service. The association has intervened to help members get driving licenses. CMPD established a SACCO for bodaboda drivers, which, in turn, has enabled an agreement with Equity Bank to provide loans to help members purchase their own motorbikes (conversation with CMPD Deputy Secretary, 2019). 
CMPD succeeded in recruiting three women who are bodaboda operators. Given dearth of women in the sector, this has greatly enhanced the reputation of the association. A less-favourable reputational aspect occurred in 2019 when the secretary of the association was accused of embezzlement of funds and was suspended from the association pending court hearing. However, this has not endangered the association, which is currently being guided by a popular and progressive leader.

\section{Umoja wa Madereva na Makondakta Tegeta Nyuki, Bunju}

Umoja wa Madereva na Makondakta Tegeta Nyuki, Bunju (UWAMATEBU) began as an informal group of daladala drivers and conductors in 2006 and was registered in 2014 in Kinondoni District of Dar es Salaam with 100 members. The group was formed in response to abuse by police and passengers and to support members injured in road crashes and funeral expenses. The association has a Board of Directors, which includes a leader from the local government of Kinondoni.

UWAMATEBU has purchased eight daladala registered to the association. This allows the association to provide temporary employment to members who find themselves with no jobs. They are expected to seek employment on other daladala within a specified period. In addition, UWAMATEBU helps conductors who lose their jobs to find temporary jobs as 'wapiga debe' ('drum beater') who help direct passengers to daladala and as fees collectors.

The constitution of the association establishes different levels of social insurance (SI). For example, TZS 100,000 (USD 43.78) is provided to support members, who have death in the immediate family. Upon death in a family, it is culturally required to leave work to care for a surviving parent, parent-in-law, or other close relative during the mourning period. Similarly, the constitution stipulates payment for those who fall ill or are involved in a crash. These funds include profits earned by the eight UWAMATEBU buses and the fees collected at bus stands.

The association has registered with the NHIF so that members can purchase health plans. However, only few members have been able to make payments to acquire the health insurance cards. UMAWATEBU has entered into agreements with local banks to give positive consideration in providing loans to their members and the association itself. In August 2017 and 2018, the association received loans from Akiba Commercial Bank (ACB) worth TZS 50 million and TZS 80 million, respectively, using as collateral land title deeds of the Chairman of the association and the local political supporter on the Board. The loans were used to purchase more buses for the association.

The key to the success of UWAMATEBU has been unusually open-minded male leaders. They actively recruited eight women conductors to become members. One of them is attending driving school, partially at the association's expense. The association promotes the notion that women are skilled individuals who should be proud to be working in daladala. These messages of worth convey upon members a strong sense of agency. 
The RC of Dar es Salaam and a local politician recognized UWAMATEBU's work and facilitated their promotion from being a route association to a daladala association representing the District of Kinondoni. The association is currently known as 'Umoja wa Madereva Wilaya ya Kinondoni' (UWAMAWIKI). ${ }^{7}$ UWAMAWIKI is registered at the District Executive Directorate and is responsible for putting in place an orderly queuing system, collection of daily dues, and welfare schemes on a district basis. Furthermore, through training, UWAMAWIKI make members aware of the laws and regulations pertaining to vehicle operation and nurture pride in occupation, which has always been looked down upon. The improved discipline enhanced the image of their members and enabled UWAMAWIKI to acquire a tender from the District to transport over 5,000 visitors from SADC countries, who gathered in Dar es Salaam for the SADC Industrialization Week, 5-9 August 2019. Although UWAMAWIKI is not fully institutionalized within the District structures, ${ }^{8}$ there exists a rulebased governance system, which, among others, enables smooth collection of government taxes.

\section{The power resources of informal transportation associations}

This section borrows from the power resources approach (PRA), which is founded on the basic premise that the workforce can successfully defend its interests by collective mobilization of power. The three examples above illustrate how informal transportation associations demonstrate varying degrees of associational, societal, and institutional power (Schmalz, Ludwig \& Webster, 2018). In comparison with the vehicle owners and business interests, drivers and conductors are generally at a disadvantage with respect to power resources, but through their capacity for collective action, the extent of their disadvantage can vary over time.

\section{Associational power}

According to Schmalz, Ludwig, and Webster (2018), associational power arises from the action of workers uniting to create collective political power as an entity such as trade union or as a worker association. The strength of associational power is associated with a number of factors such as effective organizational structure, number of members, member willingness to take action such as participating in campaigns, willingness to pay dues, and a strong collective identity.

Daladala and bodaboda groups are organized into different types of associations, whether registered or not registered with authorities. Some are organized for the purposes of mediating with police, for example, when a member runs afoul of traffic regulations or when they collectively meet with authorities to establish parking spaces. Many other associations are created mainly for the purposes of social welfare and protection. 
Most informal transport associations are not able to attract a large and stable membership. This is particularly true of bodaboda, who are in constant search of areas where there are more customers. Daladala drivers and conductors can be dismissed by their employers and are forced to go to other areas of the city. Sometimes, members cannot pay membership fees regularly as required, which limits resources available to the association leaders to network and advocate on behalf of the members. The fragmentation caused by groups breaking away from existing association to form their own association and the lack of able or trustworthy leaders further reduces the power of associations. However, information gathered through FGDs and the survey reveals that members valued being part of their small associations, as noted by members:

... in case of unfair dismissal by owner of vehicles, leaders of association accommodate one as "DAY WORKER" and contacts other associations till you find a vehicle.

(Daladala respondent, Dodoma)

...We are small, our leaders come from within us, with low education, they don't know much, and government does not listen to us...but these associations assist us to collect money when someone is sick or have an accident, but least in big issues that need solutions.

(Daladala respondent, Dar es Salaam)

\section{Societal power}

Schmalz, Ludwig, and Webster (2018) define societal power as society's support for worker demands (i.e. discursive power) and cooperation between associations and other social groups and organizations (i.e. coalitional power). An example of discursive power in Tanzania occurred on May Day in 2019 when a group of bodaboda and COTWU-T marched in Dar es Salaam with banners that read: "A Bodaboda job is like any other job". This was reported positively by the media with citizens giving testimony on how much they relied on bodaboda. This got the attention of the Dar es Salaam RC, and the Mayor of the city and bodaboda representatives were invited to their respective offices for consultation regarding their work. This "May Day" event also demonstrated coalition power of COWTU-T extending its reputation and influence to the bodaboda drivers. This had spill-over effects with police offering to provide safety and security training, banks willing to discuss provision of loans, and the NHIF making presentations on health insurance packages.

\section{Institutional power}

Schmalz, Ludwig, and Webster (2018) refer to institutional power as legally fixed rights of organized labour. At the national level, this is found in the constitution and legislation. The constitution of the United Republic of Tanzania of 1977 
establishes the right of association. The National Employment Promotion Act of 1999 gives a seat to a representative of an informal association on the National Employment Advisory Committee. This legislation was in response to massive retrenchments in the 1990s under Structural Adjustment Programs (SAPs) and the explosive growth of the informal sector, which became the refugee home of many former civil servants. There is little evidence of the committee currently being active on informal sector matters. According to the Labour Officer, the Act is currently being amended. The Employment and Labour Relations Act of 2004 under Sub-Part D: Freedom of Association gives employees the right to form and join a trade union (URT, 2004; ILO, 2004). The Act makes provision for amalgamation of registered trade unions. It prohibits the amalgamation of an unregistered unions with a registered union. Informal associations could affiliate with a registered union to gain access to its institutional power.

The Tanzania Union of Industrial and Commercial Workers (TUICO) is a notable example of a trade union extending its institutional power to the informal transportation sector. TUICO has formed coalition with bodaboda that park along the Mchikichini market, near Kariakoo in Dar es Salaam.

In addition, although short-lived, the coalition with COTWU-T enabled UWAMADAR to access COTWU-T's institutional power, and MMK is currently a branch of COTWU-T leaping on its institution power, such as representation.

The two independent transportation unions, TAROTWU, TADU, and UWAMATA (association), recognizing that they have insufficient institutional power as separate entities, are attempting to form a federation of informal transportation workers. It is uncertain as to whether their federation will attain sufficient institutional power without the support of the formal sector federations, most notably TUCTA. Unions lobby for formalization via a legal requirement that would bring 'dispersed ownership' of vehicles under a 'company', thus establishing employer-employee relationship, hence legal rights, and rights to social protection.

Apart from trade unions, some associations of informal transport workers like in the example of UWAMAWIKI above - do participate in district-level rule-based governance system related to land planning and taxation issues even if these are not formally institutionalized.

\section{Structural power}

The existence of many registered and unregistered informal transportation groups is well-known to public officials, and it is recognized that they pose a formidable mass-membership that could create considerable disturbance if provoked.

Structural power derives from the status of workers in their relationship to the economy. According to Rizzo \& Atzeni (2020), workers in the informal transportation sector in Tanzania have potential workplace structural power because of their large numbers and how widely their services are used. Bodaboda have been so hard to regulate because they "possess a certain collective power related to their large number and the service they provide: when they go on 
strike, urban transport is thrown into chaos since most of the city population depend on them" (Goodfellow \& Titeca, 2012, p.14). However, the structure of the economy, with oversupply of available labour, coupled with ease of entry requirements in the sector erodes workers' structural power as they compete in the marketplace for employment.

The competition for jobs even creates mistrust among those already working in the informal transportation sector. This was conveyed poignantly by one of the drivers of daladala in Dodoma:

...with this type of work, you learn not to trust, even your co-workers, because our jobs are not guaranteed, your co-worker knowing that he might lose his job, he can go to your "Boss" and inform him that you are not working hard enough, and that if he gets the vehicle he can bring in more money than you do, ... then abruptly, you are terminated, and the co-worker takes over the vehicle-this is common practise in our line of work.

\section{Profile of informal transportation sector respondents}

Based on the random sample survey, 50 percent of informal transport workers are association members, with the share being substantially higher in Dar es Salaam compared with Dodoma (Table 4.1). As for individual SI enrolment, the share is 17 percent overall and about double in Dodoma compared with Dar es

Table 4.1 Key worker characteristics

\begin{tabular}{lrrrrrrr}
\hline & All & & Dar & \multicolumn{3}{c}{ Dodoma } \\
\cline { 2 - 7 } & Mean & SD & Mean & SD & Mean & SD \\
\hline Association member* & 0.50 & 0.50 & 0.54 & 0.50 & 0.46 & 0.50 \\
Social insurance enrolment & 0.17 & 0.37 & 0.11 & 0.31 & 0.21 & 0.41 \\
Health insurance coverage & 0.16 & 0.36 & 0.07 & 0.25 & 0.22 & 0.41 \\
Gender (male = 1) & 0.99 & 0.11 & 0.97 & 0.17 & 1.00 & 0.00 \\
Age & 32.21 & 8.16 & 33.50 & 8.75 & 31.32 & 7.62 \\
Married & 0.52 & 0.50 & 0.53 & 0.50 & 0.51 & 0.50 \\
Locally born & 0.51 & 0.50 & 0.31 & 0.47 & 0.64 & 0.48 \\
Mean daily earnings (current USD)** & 9.86 & 16.45 & 11.71 & 19.26 & 8.59 & 14.12 \\
Assets (house and/or land) & 0.39 & 0.49 & 0.37 & 0.49 & 0.41 & 0.49 \\
Primary incomplete & 0.04 & 0.21 & 0.01 & 0.10 & 0.07 & 0.25 \\
Primary complete & 0.66 & 0.48 & 0.70 & 0.46 & 0.63 & 0.48 \\
Secondary or above & 0.30 & 0.46 & 0.29 & 0.46 & 0.30 & 0.46 \\
Professional training course & 0.25 & 0.43 & 0.23 & 0.42 & 0.26 & 0.44 \\
Training on job & 0.16 & 0.36 & 0.21 & 0.41 & 0.12 & 0.33 \\
Self-taught & 0.60 & 0.49 & 0.57 & 0.50 & 0.61 & 0.49 \\
Wage-worker & 0.32 & 0.47 & 0.27 & 0.45 & 0.34 & 0.48 \\
Own-account & 0.60 & 0.49 & 0.60 & 0.49 & 0.60 & 0.49 \\
Micro-business & 0.08 & 0.28 & 0.13 & 0.34 & 0.05 & 0.23 \\
Observations & 250 & & 102 & & 148 & \\
\hline
\end{tabular}

Source: Author's elaboration based on the project survey data.

Notes: * Association member figures are from the random sample. ** Median earnings are USD 7 for the full sample, 7.7 USD for Dar, and USD 6.6 for Dodoma. 


\section{Godbertha Kinyondo}

Salaam. The health insurance coverage is also substantially higher in Dodoma, which is likely due to the availability of CHF, currently known as iCHF (improved $\mathrm{CHF}$ ). The sector is young and male-dominated (99 percent) with an average age of 32 years, whilst around 50 percent are married. Nearly onethird (31 percent) and two-thirds (64 percent) were born in Dar es Salaam and Dodoma, respectively, a notable difference between these groups. The high migration rate among Dar es Salaam respondents mirrors the survey of ILFS (2014), which recorded 55.9 percent of residents of Dar es Salaam having migrated from other parts of the country to earn a living in a commercial city.

Mean daily earnings are around 10 USD and somewhat higher in Dar es Salaam compared with Dodoma, and this geographical difference is also reflected among bodaboda operators who negotiate rates directly with their customers. ${ }^{9}$ Dar es Salaam bodaboda earned an average of TZS 37,758 (USD 16.53) per day, while the average earning of Dodoma bodaboda was substantially lower at TZS 19,274 (USD 8.44) per day. As indicated in the footnote of Table 4.1, the median wage is USD 7 which is lower than the mean, as heavy earners at the top of the wage distribution pull up the mean. About 40 percent of the sample of workers owned a plot or a house with the share being slightly higher in Dodoma.

All respondents had some education with two-thirds (66 percent) having completed primary school and 30 percent having completed secondary school (Form IV), across locations. The relatively high level of education among transport workers was noted by a police constable in Dodoma who commented:

Given the dearth of employment for the youth, parents have opted to buy motorcycles for their Secondary School graduates to use them for business purposes, mostly, while waiting to go for further studies. But most of them end up making it their full-time jobs...

One Form IV graduate confirmed this, “... I have been here for about 3 years... when I graduated, I anticipated getting an office jobs, that dream had long vanished; bodaboda is my bread and butter".

In terms of further training, around 60 percent of the workers were selftaught, ${ }^{10}$ while 25 percent had attended a professional training course, and 16 percent had done training on the job, with the latter making up a substantially higher share in Dar. In terms of worker types, whilst a significant proportion were wage-workers (32 percent), with the share being higher in Dodoma (34 percent), the majority (60 percent) of both the Dar es Salaam and Dodoma respondents were own-account workers, and 8 percent considered themselves as micro-businesses, slightly higher in Dar. Most of the own-account workers were bodaboda ( 86.8 percent), with only few daladala drivers ( 10.3 percent) and conductors $(2.9$ percent) indicating own-account status, even though they do not own vehicles. The reasoning provided by these respondents is very revealing. "We are the ones who bring in the money for the bosses, therefore, we are the business men and not workers" (FGD, Dodoma). Another offered: 
...look here, we only hire the Boss's car to do 'our business', we handle all the logistics, make negotiations with traffic officers, and handle vehicle's technical problems for the day, while hassling to obtain enough money for the Boss, and for ourselves; without extra work and effort, you go empty handed at home.

(FGD, Dar es Salaam)

Whereas daladala workers do not generally own the vehicles, a sizable number of bodaboda own their motorcycles partially due to government initiatives (i.e. LGA Act, 1982, amended 2018) ${ }^{11}$ and often have the option of leasing the motorcycle for a specified time, usually a year, after which the bodaboda owns the motorcycle.

Looking at association members only, Table 4.2 shows that SI enrolment and health insurance coverage are only slightly higher than for the full sample, indicating that membership to associations is not a panacea to enhance formal social protection. In terms of the different types of associations, the majority (77 percent) belong to worker-type associations, followed by 22 percent being in a Saccos and Vicoba/chama. Whilst the incidence of the latter is almost double in Dodoma, the worker associations share is higher in Dar.

In Dar es Salaam, in order to access resources, training, and services such as loans, transport workers are required to form associations, and these are also encouraged as a means to facilitate taxation and self-regulation of the industry including identification of individual workers. Workers in Dodoma prefer Saccos and Vicoba as they avail funds for school fees and enable access to capital for business and daily assistance to meet consumption.

Table 4.2 Key worker characteristics, association members

\begin{tabular}{lllllll}
\hline & All & & Dar & \multicolumn{3}{c}{ Dodoma } \\
\cline { 2 - 7 } & Mean & SD & Mean & SD & Mean & $S D$ \\
\hline Social insurance enrolment & 0.18 & 0.39 & 0.15 & 0.36 & 0.21 & 0.41 \\
Health insurance coverage & 0.17 & 0.37 & 0.09 & 0.29 & 0.22 & 0.42 \\
Association type & & & & & & \\
Sacco/vicoba/chama & 0.22 & 0.42 & 0.15 & 0.36 & 0.27 & 0.45 \\
Worker association & 0.77 & 0.42 & 0.82 & 0.39 & 0.73 & 0.45 \\
Other association & 0.01 & 0.11 & 0.03 & 0.17 & 0.00 & 0.00 \\
& & & & & & \\
Benefit type & & & & & & \\
Work-related & 0.42 & 0.50 & 0.52 & 0.50 & 0.35 & 0.48 \\
Social cushioning & 0.26 & 0.44 & 0.18 & 0.39 & 0.31 & 0.47 \\
Voice and representation & 0.07 & 0.25 & 0.12 & 0.33 & 0.03 & 0.17 \\
Loans & 0.25 & 0.44 & 0.18 & 0.39 & 0.30 & 0.46 \\
Barriers & 0.80 & 0.40 & 0.79 & 0.41 & 0.80 & 0.40 \\
Fee & 0.68 & 0.47 & 0.69 & 0.47 & 0.68 & 0.47 \\
Observations & 163 & & 67 & & 96 & \\
\hline
\end{tabular}

Source: Author's elaboration based on the project survey data. 


\section{Godbertha Kinyondo}

\section{Key work-related threats and challenges}

\section{Harassment/arrest/corruption}

The survey data (see Figure 4.1) and qualitative information gathered in FGDs indicate that the greatest perceived threat faced by the workers is harassment by the authorities, most notably traffic police, who look for problems and might create them in order to extract bribes. This induces some drivers to violate traffic rules as noted below:

You have work stress, thinking of earning sufficient money, then the police stop you for no apparent reason. We, Bodaboda, have learnt to move on, even if its red lights, if police stop you, run, otherwise, they'll create a false claim to exert money from you. Imagine, this goes on the whole day.

(FGD-bodaboda, DSM)

Bodaboda particularly complain of harassment by the special police task force commonly referred to as "Tigo, 12 who monitor bodaboda in areas that the normal traffic officers do not frequent. They do not wear uniforms, move about on motorcycles, and search for thieves and criminals, including bodaboda engaged in criminal activities.

The Police are our worst enemy. They have what they call 'TIGO' who are there to catch us, this is not fair. Imagine - it's hard enough to get money for oneself, submission to boss, and then pay bribes to police.

(FGD, Bodaboda - Dar es Salaam)

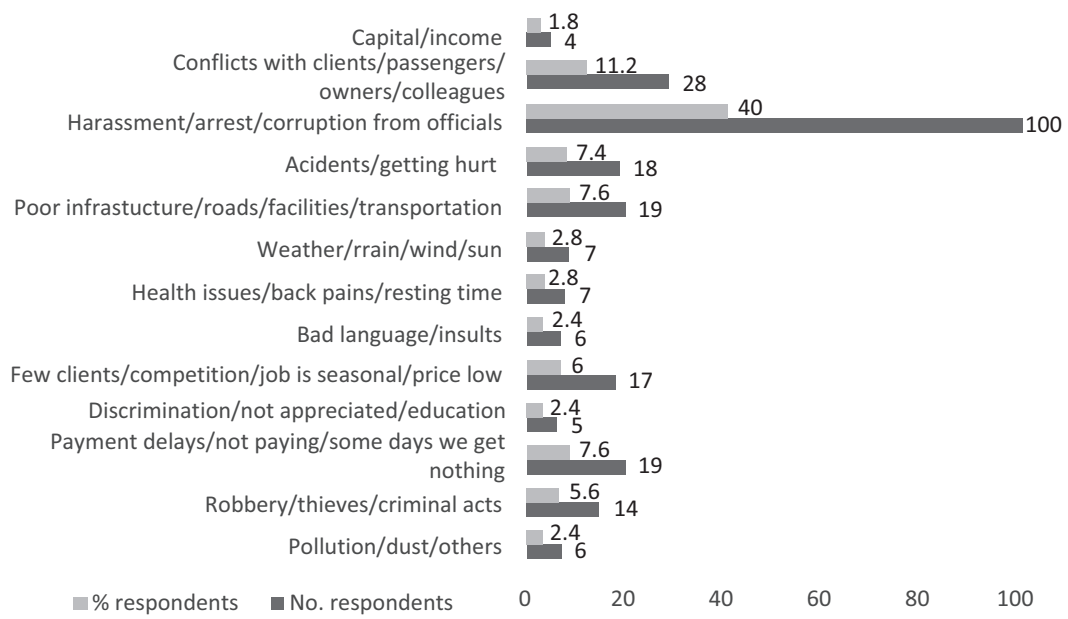

Figure 4.1 Challenges and threats facing informal transportation workers. 
Harassment allegations by authorities are documented (Cervero, 2000; Rizzo, 2011; SID, 2012; James, 2014), but police accuse the informal transport workers of failure to adhere to rules and regulations.

\section{Conflicts with clients/passengers/colleagues}

As seen in Figure 4.1, getting into conflict with passengers is the second most cited challenge. Some passengers complain of poor language, reckless driving, etc., but some mistreat workers, especially women conductors, for example, some men will refuse to pay the full fare or will flirt with them.

At times, the drivers will intervene to support their female conductors. Women also face threats of sexual harassment by drivers, who demand sexual favours before they can get and retain jobs as conductors.

...as women we face many challenges coming from unwanted sexual harassment. I have been forced to move almost five times [for refusing] drivers who wanted me...I find myself being kicked out, and sometimes they don't inform you, but you come to work, you find the driver has another conductor. There is nothing you can do; therefore, you go to look for another job.

(FGD, Daladala, DSM)

The prevailing perception of women obtaining jobs as conductors through sexual favours presents a challenge to well-intended drivers.

...many drivers would like to hire more women conductors, because women are trusted with the day collection. However, it's a problem with our wives, they forbid us from having women conductors. You face so much during the day, the only thing you need is to be confronted with your angry wife about your conductor, a woman. Almost all drivers avoid this, and those who hire women, are hard hearted.

(FGD, Dodoma)

\section{Lack of clients/lack of earnings}

When combining the two survey questions that pertain to daily earnings ("Few clients/competition/price fluctuation" and "Payment delays/non-payment/ some days we get nothing"), a number of respondents cite financial concerns as an important challenge. The issue of financial survival permeates and is interwoven throughout the testimony in FGDs.

Sometimes you see that it's getting late and that you have not gathered enough money to submit to the Boss and for your family, therefore, you do "whatever" it takes to obtain enough money for the day, there is no way out.

(FGD, Daladala Dodoma) 


\section{Social protection services facilitated by transportation associations}

This section discusses social protection as provided by the informal transportation sector associations. It borrows from the Devereux and Sabates-Wheeler (2004) framework, which conceptualizes different social protection measures as being "economic" (protective, preventive, promotive) and "social" (transformative). Protective measures, that is, cash transfers, are not covered in this study, as this is generally not something that informal associations engage with and are deemed costly. Many policy-makers promote preventive measures (i.e. health insurance), promotive measures (access to micro-finance, vocational training), and transformative (legal, institutional, social, and cultural changes that counter exploitation, discrimination, and abuse) social protection measures.

As seen in Table 4.2, the majority of workers mentioned work-related benefits, such as safety measures and higher/more stable income (promotive measures), as being the most important benefit. Bodaboda particularly appreciated safety and security because they are more prone to theft of motorcycle and their parts, kidnappings, and abductions. Daladala cited higher income as a major benefit. The second-ranked benefit by both groups is how associations provide emergency financial cushioning for education, social, and medical needs (preventive measures). The third benefit was obtaining loans (promotive measures), for example, association guarantee purchases of motorcycles on credit. Finally, voice and representation (transformative), as associations become consultative forum for members to dialogue and negotiate with authorities and other stakeholders.

Generally, both groups (daladala and bodaboda) mentioned the same association benefits, though with some differences between daladala conductors and drivers. Conductors usually depend on the goodwill from the drivers to hire and retain them, so membership in an association offers a chance to appeal to the association if a driver intends to dismiss them. Owners of buses, unless it is a family business, do not recognize conductors.

Conversely, associations are viewed as being ineffective in providing adequate support for health coverage and pensions and access to services such as water and toilets.

\section{Preventive measures}

Preventive measures aim to avert future situations that could lead to deprivation, for example, retired workers lacking sufficient savings and income, and a worker who falls ill, but cannot afford healthcare. In Tanzania, informal workers may contribute to the NSSF, NHIF, CHF, and private insurance companies such as Jubilee, AAR, etc.

As seen in Table 4.1, only 17 percent of bodaboda and daladala workers reported having formal social protection, out of which the majority were enrolled in $\mathrm{iCHF}$, followed by NHIF, NSSF, and private insurance, which is more or less in line with the enrolment pattern by the general population. Most of the formal social protection schemes are financed through the contribution of employees 
and employers, a challenge for daladala and bodaboda operators. Most owners of vehicles do not consider daladala and bodaboda operators as their employees and therefore are not legally compelled to make mandatory contributions. Those who do have formal social protection either pay for it from their own resources or have willing employers. Out of those surveyed, 38 percent pay out-of-pocket for health services and medicines, again a reflection of the out-of-pocket payments made by the general population (Ministry of Health, 2015; World Bank,2020).

There are various reasons why informal transportation workers do not contribute to health insurances with minor variation across bodaboda and daladala operators as seen in Table 4.3. First, the vast majority (90 percent) have paid no attention to health insurance and how it works, due to several reasons, but mainly, they had never encountered serious health threats. Further reasons mentioned were enrolment procedures that were too complicated and too expensive. ${ }^{13}$

Under the NHIF Mutual Plan, also known as 'KIKOA', packages were tailored to "mutual groups" such as SACCOs, VICOBA, and bodaboda groups with 20 or more members. The more affordable annual premium of TZS 76,800 (USD 33.63) per person motivated several associations to try to register. However, daladala FGD informants recounted how difficult it was to apply under the 'KIKOA' program because NHIF considered them to be employees of the bus owners. They took their case to the higher authorities and were granted permission by the minister of health to enrol in the scheme. Due to adverse selection, the KIKOA program was terminated by NHIF towards the end of 2019. Instead, individual households can voluntarily enrol in NHIF for an average annual premium of approximately (USD 357-972), per family of six, which is beyond the means of informal transportation workers who, as seen in Table 4.1, earn an average of USD 10 per day.

The premium for iCHF is far more affordable than that of NHIF. A single premium for a household of six members is TZS 150,000 (USD 17.38) in Dar es Salaam, and elsewhere, in the country, it is TZS 30,000 (USD 13.13). Informants complained that the $\mathrm{CHF}$ does not always provide the services anticipated, often requires members to pay out of pocket for some expenses, and medicines are often not available. The limited services are also a problem as observed in FGD:

Table 4.3 Reasons for not contributing to health insurance

\begin{tabular}{lccc}
\hline & Bodaboda & Daladala & Total \\
\hline Never paid attention & $90.0 \%$ & $85 \%$ & $89.6 \%$ \\
It is too expensive & $1.1 \%$ & $7.1 \%$ & $1.2 \%$ \\
I prefer to save up myself & $1.1 \%$ & $0.0 \%$ & $0.6 \%$ \\
Low quality of the insurance services & $1.1 \%$ & $0.0 \%$ & $0.6 \%$ \\
Procedures too complicated & $6.7 \%$ & $9.8 \%$ & $6.7 \%$ \\
No knowledge about insurance & $0.0 \%$ & $3.4 \%$ & $1.2 \%$ \\
Total & 90 & 73 & $100 \%$ \\
Association members & 90 & & 163 \\
\hline
\end{tabular}

Source: Author's elaboration based on the project survey data. 
You can go with CHF card and think that they will assist you, but you are told that it does not cover certain services, and thus required to pay for such services, so what is the need of the card? Imagine time lost with long ques in hospital with the card. With cash, services move fast and you get time to go back to work....

(Daladala FGD, Dar es Salaam)

Daladala and bodaboda groups and associations have arisen naturally, joining together by the social obligation to help people like themselves in need or under threat. Through these groups, money often is raised spontaneously to help a colleague in need. This is a unique cultural characteristic in Tanzania. The amount of informal fund-raising to support family, friends, and acquaintances in Tanzania is substantial. Many informal transportation worker groups put aside money in anticipation of serious illness or death of a member or close family member. This becomes an informal source of social wage and welfare protection for informal transportation workers, which helps manage the effects of precarious employment. The constitutions of many associations establish rules and regulations governing such savings.

The social dynamics among members make associations a far stronger means of SI than government sponsored programs, as observed in FGDs:

- there are different types of accidents, many of them which are common, but in case of serious injuries, which requires exorbitant medical expenses, then our leaders will pass with the Daftari-Booklet-to other associations ... for contributions. Under such circumstances, you don't think twice, but to contribute ...We have solidarity as far as such issues are concerned...

(FGD Bodaboda, DSM)

The assistance we receive from the association is fast and immediate, which give us motivation to make contributions and pay fees as required because you know when it hits, you are covered. I tell you - being in this group gives me peace of mind as you know no matter what happened, you have someone behind your back to pick you up when you fall...

(FGD, Daladala, Kijitonyama, Dar es Salaam)

\section{Promotive measures}

Promotive measures include training, strengthening human abilities, and household assets, which establish a basic foundation for households to persevere and grow. Recall from Table 4.1 that training on the job is more prominent in Dar es Salaam when compared to Dodoma because Dar es Salaam has a vast number of mainly bodaboda groups where one can start learning on the job as 'DAIWEKA' (read: day-worker). Informants during bodaboda FGDs often testified that they acquired their driving knowledge and skills by riding someone's motorcycle on parking lots. The lack of formal training on road signage, safe driving, and traffic 
laws and regulations may explain the high number of motorcycle accidents (AllAfrica, 2019; KII, Police, DSM).

The Vocational Education Training (VETA) and the National Institute of Transportation (NIT) are the main transportation training institutions. However, the training fees (tuition fees for the two weeks Driving Course is TZS 405,000 (USD 177.32) per participant) are relatively high; therefore, many drivers do not attend formal education courses. Even if the fees were lower, many informal transportation workers do not have adequate basic education to follow in the form of classroom-based theory, as noted by one FGD participant:

You know it's difficult for us sometimes to go to such schools, because we are not educated, and then they start teaching you things that are not easy to understand, why don't they only teach us how to drive? Alright, they teach a little bit of driving towards the end, thus we pick up the real knowledge of riding from our colleagues.

Transaid (2015) reports theory-based driving school's curriculum in Tanzania. Workers also need financial literacy to manage personal finance and to monitor the financial affairs of their associations. There have been several cases of association leaders embezzling funds. One association member observed:

...Our association keep on changing over time, as we group then we dismantle the group, and in most cases is due to poor financial management issues. How come other associations have reached a point of buying their own Daladala, but our association leaders do not even call general meetings as are afraid people will ask about money and we will vote them out...

(FDG, Daladala, DSM)

Associations have assisted in other promotive measures such as encouraging companies to establish lease and buy agreements with members. Also, as already highlighted, some associations were able to obtain loans to purchase buses. Motorcycle companies seek registered associations and offer members an opportunity to make a down payment and establish a schedule of weekly or monthly payments until the motorcycle is paid in full. Membership to an association provides motorcycle companies a degree of confidence that group support will ensure that payments are made as scheduled (FGD and KII,Daladala and Bodaboda, DSM and Dodoma). Some bodaboda and daladala associations have approached banks to create loan opportunities for their members (see CMPD, UWAMATEBU stories).

\section{Transformative measures}

Transformative measures aim to promote legal, institutional, social, and cultural changes that counter exploitation, discrimination, and abuse. In general, associations are involved in representation of their members as discussed in various sections in this chapter. 
Informal transportation worker associations address abuse such as police harassment and lack of contracts from the employers, but their representational power is limited. Proactively, association leaders invite police to attend association meetings to build a positive relationship. They negotiate on behalf of individuals who have been harassed. However, leaders, who themselves are on the road earning a living, must handle the cases carefully not to expose themselves to retaliation. During FGDs, the efforts of associations were appreciated by members. Both daladala workers and bodaboda operators unanimously agreed that associations effectively represent them. Associations engage with police and authorities to settle members' problems, but generally provide limited services because they are too small and weak to influence authorities. The chairman of one of the larger daladala associations provided some insights as to why the contract issue is so difficult to resolve:

...there is no will on the side of the government. This is because most of the policy makers are owners of the vehicles and thus are not interested in listening to the grievances of the drivers. We have been talking for years, but it falls on deaf ears.

Some FGD participants expressed concerns that the push for contracts might backfire. If owners were required to pay salaries and benefits, this would upset the current arrangement that allows drivers to earn additional money after paying the set daily target, as noted by a daladala driver:

I don't think that a Daladala owners can sincerely agree to pay salaries to drivers. If so, it'll pose a big problem for drivers. If you enter an agreement for a salary, the boss will raise the daily rate and impose stringent measures till you're left with nothing. If you don't comply, he can fire you by just saying just park a vehicle. So, you can say this is not a formal job, unless they are forced to do so, and monitored for compliance, it won't work on our favour.

\section{Discussion}

The associations are important for workers in terms of provisions of social protection to members, albeit to a limited extent. This section reviews association entry conditions, makes comparisons between association members and non-members, and explores similarities between workers that are enrolled in formal SI versus those that are not.

\section{Access to informal transportation sector associations}

In order to be a member of an informal transportation worker association, one must have access to a vehicle ${ }^{14}$ registered for business and a driving license. As shown in Table 4.2, 80 percent of respondents admit that there are barriers to enter the association. There may also be a probationary period, which daladala 
associations use to determine if a prospective member is a reliable business operator.

...when the driver wants to join our association, leaders welcome you, then they monitor you, for 3 or 6 months, if they see you as not troublesome, and that you can contribute up to TZS 4,000 (USD 1.75), for the total trips you make per day, they accept you and then they register you as member.

(FGD Daladala, DSM)

The observation time also takes into account that a prospective member might not stay for long, “... you can register your bus to a route, but after four days, you may decide to change the route" (FGD, Daladala DSM).

Bodabodas are associated with reckless driving, crime, accidents (James, 2013; Xinhua, 2018) operating without licenses, but, in general, bodaboda associations use the initial period to observe behaviour.

...we started our association with a group of 18 members, but we found that other members are misbehaving, which was tainting our group. Then we changed our constitution and imposed tougher measures. We required IDs, set dress code, orderly parking of motorcycle to avoid competition for passengers. Such measures forced 10 members to drop out of the association; we are currently 8 only. Our business is booming, as we have created a good reputation in the community. We have consistent clientele, i.e. school children, elderly and grocery shopping for clients etc.

(FGD, Bodaboda, Dodoma)

Most associations (68 percent) require payment of entry fees, which varies depending on the size of the association. Entry fees can be a deterrent to enter certain associations, especially for daladala drivers. One FGD informant observed, “...to join UWAMASTEBU you should have at least Tsh 250,000 (USD109.46), an exorbitant amount for many people to afford" (FGD, Daladala).

Other associations charge an entry admission fee of TZS 50,000 or more, while some association deter charging fees until a member has started earning money. Each driver pays to the association TZS 500-1,000 (USD 0.22-0.45) per trip. The monthly membership contribution varies between TZS 2,000 and 5,000 (USD 0.90-2.19).

\section{Comparison between association members versus non-members}

According to Pieterse (2008), collective action provides avenues for articulating group interests and agendas and for claiming rights. Some associations offer members access to group health care benefits and other perks that nonmembers lack. Table 4.4 shows the comparison between members of associations and non-members along a number of characteristics and other factors based on the survey data. As recalled from Table 4.2, SI enrolment and health insurance 


\section{Godbertha Kinyondo}

Table 4.4 Differences in key workers characteristics by association member status

\begin{tabular}{lccrr}
\hline & Member & Not Member & Difference & t-Value \\
\hline Social insurance enrolment & 0.18 & 0.14 & 0.05 & 0.93 \\
Health insurance coverage & 0.17 & 0.14 & 0.03 & 0.57 \\
Dar & 0.41 & 0.40 & 0.01 & 0.13 \\
Dodoma & 0.59 & 0.60 & -0.01 & -0.13 \\
Gender (male = 1) & 0.98 & 1.00 & -0.02 & -1.27 \\
Married & 0.54 & 0.48 & 0.06 & 0.86 \\
Local & 0.48 & 0.55 & -0.07 & -1.01 \\
Age & 32.61 & 31.45 & 1.17 & 1.08 \\
Mean daily earnings (current USD) & 10.25 & 9.12 & 1.13 & 0.52 \\
Assets (house and/or land) & 0.42 & 0.34 & 0.07 & 1.11 \\
Primary incomplete & 0.04 & 0.06 & -0.02 & -0.76 \\
Primary complete & 0.67 & 0.63 & 0.04 & 0.58 \\
Secondary or above & 0.29 & 0.31 & -0.02 & -0.26 \\
Training course & 0.26 & 0.23 & 0.03 & 0.48 \\
Training on job & 0.15 & 0.16 & -0.01 & -0.16 \\
Self-taught & 0.59 & 0.61 & -0.02 & -0.31 \\
Wage-worker & 0.33 & 0.30 & 0.03 & 0.42 \\
Own-account & 0.55 & 0.69 & -0.14 & $-2.12^{* *}$ \\
Micro-business & 0.12 & 0.01 & 0.11 & $3.06^{* * *}$ \\
Observations & 250 & & & \\
& & & & \\
\hline
\end{tabular}

Notes: $<0.01^{* * *},<0.05^{* *},<0.1^{*}$.

Source: Author's elaboration based on the project survey data.

coverage were only slightly higher for members than for the full sample, indicating that membership is only marginally conducive to enhanced insurance, which is confirmed in Table 4.4 indicating no significant difference along that dimension.

Across most dimensions, association members do not differ significantly from non-members. They have similar educational profiles, the majority are Primary School leavers, but FGD discussions indicated that more educated workers are joining associations with the intentions of taking over leadership roles (FGD, Dodoma, and Dar es Salaam), in order to raise their visibility in leadership, and eventually run for political offices.

In terms of worker types, wage-workers are equally likely to be association members as well as non-members, but own-account workers are more likely not to be association members. This is because they often have their own means to obtain the kind of support that associations provide. Oppositely, microbusinesses (47.6 percent daladala, 4.8 percent conductors; 47.6 percent bodaboda) might join associations because they provide a new business owner with contact to other local businesses that facilitates integrating into the community and access to financial services, that is, SACCOs. Schleifer and Nakagaki (2018) report that, as entrepreneurs grow, they seek larger, commercial bank loans. One of the requirements for micro-businesses to access loans from the financial institutions in Tanzania is to belong to registered associations. 
Despite the statistical insignificance, members of associations tend to earn slightly more than non-members. Members noted that associations help them be more financially disciplined. One FGD informant commented, "The money discipline put within our associations enable us to earn, and utilize fund properly. At the end of the day, you have more money than the guys who owns their motorcycles as they lax because have no submissions" (FGD Bodaboda). This was further illustrated by an FGD participant:

...associations teach financial prudence, but people belittle us, even my own brother refers my work in a derogatory manner. [wewe Bodaboda tu], and yet I earn more than he does, despite working for the government. Ironically, he borrows money from me.

(FDG, Bodaboda, Dar es Salaam)

\section{Comparison between formal social insurance of association members versus non-members}

Table 4.5 compares respondents in the informal transportation sector who are enrolled in formal SI (including health insurance and pension) with those who are not enrolled. Again, whilst association members are more likely to have social insurance (SI) than not, the difference is not significant. Workers in Dar are significantly more likely not to have formal insurance, whereas the opposite is the case in Dodoma. One reason is that SI schemes are more expensive in Dar es Salaam than in Dodoma. In Dar es Salaam, iCHF costs TZS 150,000 (USD 65.67) per household of six/year; the same size household pays TZS 30,000 (USD 13.13) in Dodoma and other areas of the country. The reason is that general earnings and costs are higher in Dar es Salaam because of high population density (1,786 per $\mathrm{km}^{2}$ ) (NBS, 2014b; NBS, 2016), which poses health risk, raising higher health seeking behaviour. Furthermore, iCHF objective includes access and coverage of the poor and vulnerable.

The results also show that the completion of Secondary school or above increases the likelihood of enrolment, while those who only attended primary school lag behind in enrolment. This supports the observation by Zajacova and Lawrence (2018) that more education increases the ability to comprehend the preventive value of health insurance.

Finally, own-account owners are more likely not to have formal social insurance because they have resources to provide alternative. Also, poor membership to associations excludes own-account workers from access to affordable health schemes tailored to associations members, for example, KIKOA, whilst wage-workers who have a comparatively higher associations membership share are able to benefit more from group health schemes.

To improve overall enrolment rates, formal SI packages must include appropriate contribution methods, acceptability measures, and benefit packages that befit the needs of informal transport sector workers. This ought to consider 


\section{Godbertha Kinyondo}

Table 4.5 Differences in key workers characteristics by social insurance enrolment

\begin{tabular}{|c|c|c|c|c|}
\hline & $\begin{array}{l}\text { Social } \\
\text { Insurance }\end{array}$ & $\begin{array}{l}\text { No Social } \\
\text { Insurance }\end{array}$ & Difference & $t$-Value \\
\hline Association member & 0.71 & 0.64 & 0.07 & 0.93 \\
\hline Sacco/vicoba/chama & 0.19 & 0.13 & 0.06 & 0.94 \\
\hline Work-related association & 0.52 & 0.50 & 0.03 & 0.34 \\
\hline Women/youth/religious & 0.00 & 0.01 & -0.01 & -0.64 \\
\hline Work-related & 0.33 & 0.26 & 0.07 & 0.91 \\
\hline Loans & 0.24 & 0.15 & 0.09 & 1.42 \\
\hline Voice and representation & 0.05 & 0.04 & 0.00 & 0.12 \\
\hline Social cushioning & 0.10 & 0.18 & -0.09 & -1.38 \\
\hline Dar & 0.26 & 0.44 & -0.18 & $-2.12^{\star *}$ \\
\hline Dodoma & 0.74 & 0.56 & 0.18 & $2.12^{* *}$ \\
\hline Gender $($ male $=1)$ & 0.98 & 0.99 & -0.01 & -0.77 \\
\hline Married & 0.57 & 0.51 & 0.06 & 0.73 \\
\hline Local & 0.55 & 0.50 & 0.05 & 0.56 \\
\hline Age & 33.98 & 31.85 & 2.13 & 1.54 \\
\hline $\begin{array}{l}\text { Mean daily earnings (current } \\
\text { USD) }\end{array}$ & 10.91 & 9.65 & 1.27 & 0.46 \\
\hline Assets (house and/or land) & 0.43 & 0.38 & 0.04 & 0.53 \\
\hline Primary incomplete & 0.00 & 0.05 & -0.05 & -1.53 \\
\hline Primary complete & 0.52 & 0.68 & -0.16 & $-1.98^{* *}$ \\
\hline Secondary or above & 0.48 & 0.26 & 0.21 & $2.76^{* * *}$ \\
\hline Training course & 0.33 & 0.23 & 0.10 & 1.40 \\
\hline Training on job & 0.12 & 0.16 & -0.04 & -0.72 \\
\hline Self-taught & 0.55 & 0.61 & -0.06 & -0.70 \\
\hline Wage-worker & 0.48 & 0.28 & 0.19 & $2.47 * *$ \\
\hline Own-account & 0.40 & 0.64 & -0.23 & -2.87 *** \\
\hline Micro-business & 0.12 & 0.08 & 0.04 & 0.90 \\
\hline Observations & 250 & & & \\
\hline
\end{tabular}

Source: Author's elaboration based on the project survey data.

Notes: $<0.01^{* * *},<0.05^{* *},<0.1^{*}$.

the fragility of the associations and thus the need for capacity-building of such associations.

\section{Conclusion}

This chapter assessed the relevance of informal transport associations for the provision of social protection to daladala and bodaboda workers. Despite poor regulatory environment, these workers are required by law to comply with formal regulatory requirements, such as obtaining drivers' licenses, paying vehicle insurance, parking in designated areas, wearing helmets, and plying specified routes. The vehicle owners require the drivers of daladala and bodaboda to pay a specified daily amount. Vehicle owners provide no social protection and do not comply with labour laws, and the government does not consider the informal transportation workers as parties under employer-labour relations regulations. Therefore, informal transportation workers view themselves as operating a business. Generally, informal transportation workers in Tanzania operate in both a world of formal and informality. 
Informal transportation worker associations have emerged as a means of self-regulation in the face of government inability to regulate the sector, and members realize social protection benefits that derive from organizing themselves in associations. Power resource analysis shows that informal transport associations in Tanzania have inadequate structural power due to an oversupply of workers that gives vehicle owners the ability to set the terms of employment. The inability and unwillingness of the government to intervene strengthen the negotiation position of the owners of vehicles.

The workers demonstrate associational power by voluntarily forming informal sector associations. These associations provide preventive and promotive services such as provision of partial financial support to members who fall ill or victim to accidents, educating members about formal health insurance and pension schemes, spearheading driver's trainings that facilitate getting licenses for those who don't have them, assisting access to loans from banks, and providing shortterm unemployment opportunities. Despite shortfall, informal transportation workers enjoy strong support from customers along their routes, and the workers on occasion have used this societal power to gain the attention of political leaders. But informal transport worker association lacks adequate institutional power to force government agencies to provide relevant social welfare programmes and schemes.

Generally, associations have a better comprehension of the felt needs, priorities, and contributing capabilities of the informal transport workers when compared with the formal sector institutions. The formal SI schemes offered by the government, that is, KIKOA, have not been consistent and successful in their outreach to the informal sector. The NHIF offers packages that are costly, and the CHF packages are deemed ineffective, as they fail to meet the needs of workers. The capacity of informal transportation associations must be enhanced in order to provide them the strength to be included in the policy-making process.

\section{Notes}

1 More than 70 percent of Dar es Salaam residents reside in unplanned areas with no convenient access to formal transportation and therefore rely on the informal transportation system (Ka'bange et al., 2014).

2 The terminated funds were the Local Authority Pension Fund (LAPF), Public Services Pension Fund (PSPF), Government Employees Pension Fund (GEPF), Public Pension Fund (PPF), and the National Social Security Fund (NSSF).

3 Poor coverage. According to Jacob and Pedersen (2018), only l percent of the population is covered by the NSSF.

4 Teachers, Hotels, Doctors, etc. left COTWU to form their sector-specific unions.

5 Interviews with COTWU-T IEDO, Training Manager, and Secretary General.

6 Source: Interviews with the association Chairman, and FGD Discussions, DSM.

7 UWAMAWIKI is composed of three routes associations UWAMASTEBU, UWAMAMAPO, and UWAMATEBU.

8 While they are not included in formal structures of the District, a representative from their group is involved in meetings and workshops pertaining to issues relevant to them, including land planning and taxation.

9 For daladala operators, LATRA sets the rates. 
10 High level of self taught, contributes to poor adherence of rules and regulations of road safety thus contributing to higher rates of road traffic crashes.

11 Requires each LGA to set aside 4 percent of its revenue collection as a no-interest loan to youth.

12 Referring to the first mobile cellular network in Tanzania.

13 The same sentiments were echoed during FGDs in both DSM and Dodoma.

14 Vehicle refers both to motorcycles and daladala buses.

\section{References}

AllAfrica (2 September 2019) Tanzania: Road accidents down 27\% - Report. AllAfrica. Available from: https://allafrica.com/stories/201909020347.html.

Cervero, R. (2000) Informal transport in the developing world. United Nations Center for Human Settlements, UN-Habitat. Available from: http://mirror.unhabitat.org/pmss/ getElectronicVersion. aspx?nr=1534\&alt=1.

Devereux, S. \& Sabates-Wheeler, R. (2004) Transformative social protection. IDS Working Paper 232. Brighton, Institute of Development Studies.

Equity Bank loans assist members purchase their own motorbikes (conversation with CMPD Deputy Secretary, January 12, 2019).

Goodfellow, T. \& Titeca, K. (2012) Presidential intervention and the changing 'politics of survival' in Kampala's informal economy. Cities. 29 (4), 264-270. Available from: doi:10.1016/j.cities.2012.02.004.

ILFS (2014) Integrated labour force survey in Tanzania. Dar es Salaam, National Bureau of Statistics.

ILO (2004) Tanzania employment and labour relations Act, No. 6 of 4 June 2004. International Labour Organization. Geneva, International Labour Office. Available from: https:// www.ilo.org/dyn/natlex/docs/ELECTRONIC/68319/104204/F-894240970/ TZA68319.pdf.

ILO (2018) Social protection for older persons: Policy trends and statistics 2017-19. International Labour Organization. Geneva, International Labour Office, Social Protection Department. Available from: https://www.ilo.org/secsoc/information-resources/ publications-and-tools/policy-papers/WCMS_645692/lang--en/index.htm.

Jacob, T. \& Hundsbrk Petersen, R. (2018). Social protection in an electorally competitive environment (1): The politics of Productive Social Safety Nets (PSSN) in Tanzania. ESID Working Paper 109. Manchester: Effective States and Inclusive Development Research Centre, The University of Manchester.

James, B. (17 August 2013) Inside boda boda crime syndicates. The Citizen. Available from: http://www.thecitizen.co.tz/News/national/Inside-bodaboda-crime-syndicates/ 1840392-1958102-fqealk/index.html.

James, B. (2 November 2014) Terror as boda boda theft rises. The Citizen. Available from: http://www.thecitizen.co.tz/news/national/terror-as-bodaboda-theft-rises/ 1840392-2507796-54duqh/index.html.

Ka'bange, A., Mfinanga, D. \& Hema, E. (2014) Paradoxes of establishing mass rapid transit systems in African cities. A case of Dar es Salaam Rapid Transit (DART) system, Tanzania. Research in Transportation Economics, 48. doi:10.1016/j.retrec.2014.09.040

Mbegu, S. \& Mjema, J. (2019) Poverty cycle with motorcycle taxis (boda-boda). Business in developing countries: Evidence from Mbeya-Tanzania. Open Access Library Journal. 6 (e5617). Available from: doi:10.4236/oalib.1105617 [Accessed 2 March 2020]. 
Membership ID Cards protects informal transport workers from harassment (FGD with MMK, February 22, 2019)

Ministry of Health (17 March 2015) Tanzania health financing strategy 2015-2025: Path towards universal health coverage, $3 \mathrm{rd}$ draft. Ministry of Health and Social Services, Dar es Salaam, unpublished.

NBS (2014a) Mainland Tanzania: Formal sector employment and earnings survey analytical report 2013. National Bureau of Statistics of Tanzania. Dar es Salaam, Ministry of Finance.

NBS (2014b) Population and housing census: Basic demographic and socio-economic profile, Dar es Salaam region. National Bureau of Statistics of Tanzania. Dar es Salaam, Ministry of Finance.

NBS (2016) The 2012 population and housing census. National Bureau of Statistics of Tanzania. Dar es Salaam, Ministry of Finance.

PDL (2014) Labour and employment law overview for Mainland Tanzania (unpublished). People Dynamics Limited (rev. September 2014).

Pieterse, E. (2008) City futures: Confronting the crisis of urban development. London \& New York, Zed Books.

Rizzo, M. (2011) 'Life is war': Informal transport workers and neoliberalism in Tanzania 1998-2009. Development and Change. 42 (5), 1179-1206. Available from: doi:10.1111/j.1467-7660.2011.01726.x.

Rizzo, M. \& Atzeni, M. (2020) Workers' power in resisting precarity: Comparing transport workers in Buenos Aires and Dar es Salaam. Work, Employment and Society. 34 (6), 1114-1130. Available from: doi:10.1177/0950017020928248.

Schleifer, M. \& Nakagaki, M. (2018) Empowering women entrepreneurs in Bangladesh. In: Strategies for policy reform volume 3: Case studies in achieving democracy that delivers through better governance. Washington D.C., Center for International Private Enterprise.

Schmalz, S., Ludwig, C. \& Webster, E. (2018) The power resources approach: Developments and challenges. Global Labour Journal. 9 (2), 113-134.

SID (2012) Informal transport sector workers in the GHEA: A perspective from the driver's seat. The SID Forum, Society for International Development. Available from: http:// www.sidint.net/docs/RF22_Informal_Transportation.pdf.

Transaid (2015) Tanzania motorcycle taxi rider training: Assessment and development of appropriate training curriculum. Transaid. Thame, UK, Cardno Emerging Market (UK), Ltd. Available from: http://www.research4cap.org/Library/TRANSAID-2015MotorcycleTaxi-Training-Fin Rept-AFCAP-TAN2015E-AnnexA-Curriculumv150616.pdf.

TUCTA (2015) Draft policy statement for the informal sector. Secretary General, Msigwa, Trade Union Congress of Tanzania (TUCTA), Dar es Salaam.

UNICEF (2018) Health budget brief. UNICEF - Tanzania Mainland. Available from: https://www.unicef.org/esa/media/2331/file/UNICEF-Tanzania-Mainland-2018Health-Budget-Brief-revised.pdf.

URT (2003) National transport policy. Ministry of Communication and Transport, Tanzania. Available from: https://www.tanzania.go.tz/egov_uploads/documents/ National_Transport_Policy_2003_sw.pdf.

URT (2004) The employment and labour relations act of 2004. United Republic of Tanzania. Available from: https://www.tanzania.go.tz/egov_uploads/documents/ Employment\%20and\%20LAbour\%20Relation\%20Act_1.pdf. 


\section{Godbertha Kinyondo}

Vanguard (7 November 2018) How motorcycle accidents killed 800 in Tanzania. Vanguard. Available from: https://www.vanguardngr.com/2018/11/howmotorcycle-accidents-killed-800-in-tanzania.

Wang, H., Juma, M.A., Rosemberg, N. \& Ulisubisya, M.M. (2018) Progressive pathway to universal health coverage in Tanzania: A call for preferential resource allocation targeting the poor. Health Systems \& Reform. 4 (4), 279-283.

World Bank (2020) Out-of-pocket expenditure (\% of current health expenditure) Tanzania. World Bank. Available from: https://data.worldbank.org/indicator/ SH.XPD.OOPC.CH.ZS locations=TZ.

Xinhua (2018) Motorcycle accidents in Tanzania kill 800 people annually. Xinhua. Available from: http://www.xinhuanet.com/english/africa/2018-11/07/c_137589980.htm.

Zajacova A. \& Lawrence, E.M. (2018) The relationship between education and health: Reducing disparities through a contextual approach. Annual Review of Public Health. $39,273-289$. 